Biol. Stud. 2014: 8(1); 11-28 • DOI: https://doi.org/10.30970/sbi.0801.322

www.http://publications.Inu.edu.ua/journals/index.php/biology

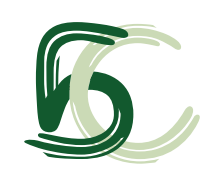

UDC: [504.064:577.25](564.141)

\title{
MOLECULAR RESPONSES OF THE BIVALVE MOLLUSKS FROM THE COOLING POND AS A MODEL FOR PREDICTION OF CONTEMPORARY ENVIRONMENTAL CHALLENGES
}

\author{
Lesya L. Gnatyshyna', Olga O. Turta', Iryna V. Yurchak', \\ Nataliya I. Boyko ${ }^{1}$, Alla Ye. Mudra', Halyna I. Falfushynska ${ }^{1,2}$, Oksana B. Stoliar \\ ${ }^{1}$ Ternopil V. Hnatiuk National Pedagogical University, 2, M. Kryvonis St., Ternopil 46027, Ukraine \\ e-mail: Oksana.Stolyar@gmail \\ 2I.Ya. Horbachevsky Ternopil State Medical University, 1, M. Voli St., Ternopil 46001, Ukraine
}

To reveal a potential combined effect of pollution and continuos warming towards freshwater organisms, the molecular responses of stress and toxicity were compared during two years in the bivalve mollusks Anodonta anatina from the cooling pond of Khmelnytskyi Nuclear Power Plant (N-group) and from the ponds in the forestry (F-group) and agricultural (A-group) areas. Using Classification and Regression Tree (CART) software on the basis of a set of studied markers, characteristics for the distinguishing of N-group were selected. Firstly, it was the constantly elevated level of the vitellogenin-like protein in gonads and hemolymph of male specimens that witness the effect of endocrine disruption. The mussels of $\mathrm{N}$-group demonstrated on oxidative injury with highest values of the Index of inter-seasonal variability for oxidized glutathione and metallothionein-related thiols among three groups, and constantly high level of apoptotic activity in the digestive gland. Remarkably higher levels of copper and cadmium within the tissues were detected in the N-group reflecting the industrial pollution. These metals were preferentially bound to metal-buffering protein metallothionein. A combination of these characteristics demonstrates that stable elevated temperature jointly with industrial pollution caused a partial apoptotic elimination of cells with the nuclear lesions and provoked the exceeding of resistance of stress-related responses and reproduction-related functions in the mussels.

Keywords: Anodonta anatina, warming effect, pollution, metallothioneins, apoptosis, oxidative injury, endocrine disruption.

\section{INTRODUCTION}

Traditionally, at the assessment of environmental toxicity main attention is paid to individual hazardous substances that derived from pointed sources and caused big accidental spills [8]. However, novel environmental challenges biorisks are mainly connected to the complexity of harmful effects $[6,24,35,38,45]$. It is inconstant in time, composition, and its effect is difficult to be predicted. In these circumstances, typical responses of habitants to adverse effects can be distorted. Moreover, the resilience of

ISSN 1996-4536 (print) • ISSN 2311-0783 (on-line) • Біологічні Студії / Studia Biologica • 2014 • Том 8/№1 • C. 11-28 
the adaptive responses of aquatic organisms is likely to be exceeded this century by an unprecedented combination of climate change, associated environmental disturbances, and other global change drivers resulting from the effects of novel and traditional pollutants $[11,42]$ that can distort the responses of certain biomarkers.

With the view to study the effect of climate changes, the specimens from the cooling ponds represent very attractive models. They are subjected to constantly elevate ambient temperature. However, present information concerning the responses of animals from these aquatic bodies is scant and related mostly to genotoxic consequences of nuclear accident in Chornobyl, Ukraine [18, 19, 22]. For the working nuclear power plants, the absence of effects of heated water discharge for aquatic animals based on morphology and community study was demonstrated [40].

Bivalve mollusks are recommended to utilize as a sentinels of environmental pollution due to their sedentary nature, filter-feeding behavior and ability to accumulate pollutants. Mainly, their biomarkers of oxidative stress are utilized for the evaluation of non-specific inappropriate effects. For the marine mollusks, the markers of genotoxicity and cytotoxicity are also often reported to be sensitive to environmental changes indices [44]. Among markers of exposure to specific pollutants, only metallothionein (MT), the marker of biologically available toxic metals $(\mathrm{Cd}, \mathrm{Cu}, \mathrm{Zn}, \mathrm{Hg})$, is entirely approved for utilization in mollusks [25, 44].

Particular care is needed when biomarkers are used for pollution assessment in case of in-field studies due to the influence of different factors like environmental variables, high seasonal variability, and the complexity of pollutant mixtures causing additive, synergistic or opposite effects on the measured molecular and/or cellular responses. Therefore, estimation of environmental effect via comparison of specimens from at least three areas meets desirable demand of field studies [12]. However, these limitations are described mostly for marine mollusks [21, 44] whereas studies of biochemical markers in the indigenous freshwater mollusks are scant [5, 20, 35, 46]. Results based on biological responses to potentially dangerous inputs of anthropogenic loads in freshwater environments in the Western Ukraine are rather rare [14, 15, 42].

Taking into consideration contemporary trends to strengthen complex environmental pressure, including global climate changing and local temporal effects of pollution, and prospective value of bivalve mollusk as sentinel species, the aim of this study was to distinguish stress-related molecular response of bivalve mollusk Anodonta anatina from the cooling pond in comparison with the responses of mussels that are subjected only the consequences of spontaneous pollution. Biomarker measurements were performed in the respiratory organ, the gills as the first target tissue for contaminants, digestive gland as metabolically active tissue and in the hemolymph.

\section{MATERIALS AND METHODS}

Experimental Groups. The experiments were carried out during the middle of May, July and September of 2009 and during the September of 2010 (I, II, III and IV periods, correspondingly). Specimens of Anodonta anatina were collected manually from 0.5-1 $\mathrm{m}$ depth in three sites located in the Galicia-Volyn region, Western Ukraine (Fig. 1). The forestry $(F)$ site is located in the upstream portion of river Seret (near the village Ivachiv, $49^{\circ} 49^{\prime} \mathrm{N}, 25^{\circ} 23^{\prime} \mathrm{E}$ ) where no industrial contamination could be detected, and close to the area of municipal water inlet. The agricultural $(A)$ site is situated in the lower

ISSN 1996-4536 (print) • ISSN 2311-0783 (on-line) • Біологічні Студії / Studia Biologica • 2014 • Том 8/№1 • C. 11-28 
portion of the Nichlava River near the boroughs of the city of Borshchiv $\left(48^{\circ} 48^{\prime} \mathrm{N}\right.$, $26^{\circ} 00^{\prime} \mathrm{E}$ ) that receives effluents from the region with intense agricultural activity and also from the city, in which a creamery is the most prominent source of pollution and the waste water plants are absent. The site with stable higher temperature of water $(\mathrm{N})$ is located on the southern bank of the cooling pond of Khmelnytskyi Nuclear Power Plant (NPP) in Netishyn (in forestry area on the tributary of river Horyn, $50^{\circ} 21^{\prime} \mathrm{N}$, $\left.26^{\circ} 38^{\prime} \mathrm{E}\right)$. The connection by water between these three sites is absent, distance is about 100-200 km, so we may confirm that mollusks from three sites represent three different populations.

Fig. 1. Localization of sampling sites in the Galiciau-Volyn area, Western Ukraine. Sites: 1, F (forestry, reference); 2, A (agricultural); 3, N (cooling pond of nuclear power plant).

Рис. 1. Розташування ділянок дослідження Галицько-Волинського регіону Західної України. Ділянки: 1, F (лісова, рефенційна); 2, А (аграрна); 3, N (водойма-охолоджувач атомної електростанції)

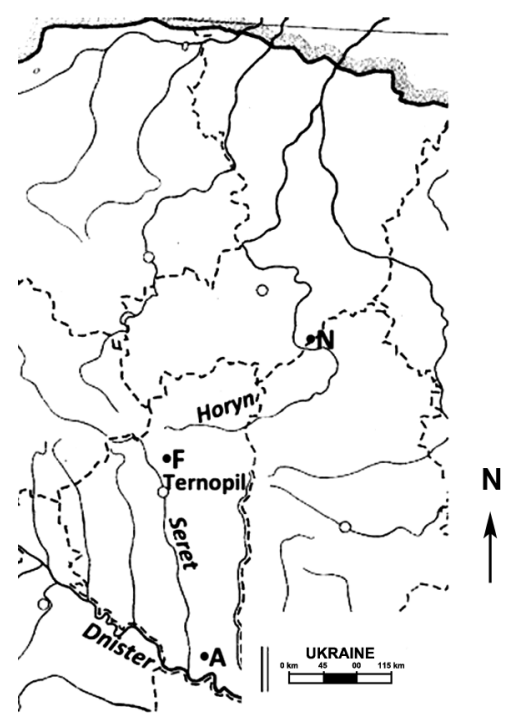

The samplings were carried out simultaneously in all sites. Individuals were transported to the laboratory in cages with native water and treated within a day after the sampling procedure. Water samples were also collected and transferred to the laboratory in iced packs for the determination of chemical parameters. For each biochemical parameters eight digestive glands, gills and hemolymph samples were prepared individually. Each procedure of tissue analysis was carried out at a temperature around $4{ }^{\circ} \mathrm{C}$. Micronuclei were determined in the hemocytes, vitellogenin-like protein - in the gonads and hemolymph, all other biomarkers - in the digestive gland and/or gills.

Tissues were homogenized $(1 / 10 \mathrm{w} / \mathrm{v})$ in $0.1 \mathrm{M} \mathrm{pH} 7.4$ phosphate buffer containing $100 \mathrm{mM} \mathrm{KCl}$ and $1 \mathrm{mM}$ EDTA as well $0.1 \mathrm{mM}$ PMSF for the inhibition of proteolysis. Homogenates were centrifuged at $6000 \times g$ for $10 \mathrm{~min}$ and the resulting supernatant was used immediately for measurement.

For the measuring of enzyme activities, tissue was homogenized $(1 / 10 \mathrm{w} / \mathrm{v})$ in $0.1 \mathrm{M} \mathrm{pH} 7.4$ phosphate buffer containing $100 \mathrm{mM} \mathrm{KCl}$ and $1 \mathrm{mM}$ EDTA as well $0.1 \mathrm{mM}$ PMSF for the inhibition of proteolysis. Homogenates were centrifuged at $6000 \times g$ for $10 \mathrm{~min}$ and the resulting supernatant was used immediately for measurement. The protein concentration in the supernatant was determined by the method of Lowry et al. (1951) using bovine serum albumin as the standard [30].

ISSN 1996-4536 (print) • ISSN 2311-0783 (on-line) • Біологічні Студії / Studia Biologica • 2014 • Том 8/№1 • C. 11-28 
Chemicals. Products: 5,5'-dithio-bis(2-nitrobenzoic acid) (DTNB), thiobarbituric acid (TBA), reduced glutathione (GSH), glutathione reductase, 2-vinylpyridine, serum albumin, phenylmethylsulfonyl fluoride (PMSF), $\beta$-mercaptoethanol, NADH, NADPH, Sephadex G-50, acetyl-Asp-Glu-Val-Asp p-nitroanilide, t-butyl methyl ether were purchased from Sigma. All other chemicals were of analytical grade.

Measurement of Body Indices. In each group individual's length, total, whole soft body, shell and separate tissues weight were recorded. The condition index $(\mathrm{Cl})$ of the tissues was calculated as the ratio: (drained mass of organ/soft tissues weight) $\times 100$, the condition factor (CF) as the ratio: (total weight of mollusks/(shell length) $\left.)^{3}\right) \times 100$.

Markers of Stress. Catalase (CAT, EC 1.11.1.6) activity was measured by monitoring the decomposition of $10 \mathrm{mM} \mathrm{H}_{2} \mathrm{O}_{2}$ according to Aebi (1974) at $240 \mathrm{~nm}\left(\varepsilon=40 \mathrm{M}^{-1} \cdot \mathrm{cm}^{-1}\right)$ in a buffer containing $50 \mathrm{mM} \mathrm{KH}_{2} \mathrm{PO}_{4}(\mathrm{pH} \mathrm{7.0)}$ and approximately $150 \mu \mathrm{g}$ of proteins [1]. Results were related to the soluble protein.

Total glutathione concentration was quantified by the glutathione reductase recycling assay [2]. To estimate the oxidized glutathione (GSSG) level, the protein free sample was treated with 2-vinylpyridine prior to assay run (60 min) at $2 \%$ final concentration [23]. The rate of 5-thionitrobenzoic acid formation was monitored spectrophotometrically at $412 \mathrm{~nm}$. The redox-index of glutathione (RI GSH) as the ratio of concentrations ([Total glutathione]-[GSSG])/[Total glutathione] was also calculated. Standards were prepared from reduced glutathione, and concentrations were expressed as $\mu \mathrm{mol}$ per $\mathrm{g}$ wet weight.

Lipid peroxidation (LPO) was determined in the supernatant of $1 / 10 \mathrm{w} / \mathrm{v}$ homogenate by the production of TBA-reactive substances (TBARS) [32]. A molar extinction coefficient of $1.56 \cdot 10^{5} \mathrm{M}^{-1} \cdot \mathrm{cm}^{-1}$ was used.

The activity of lactate dehydrogenase (EC 1.1.1.27) was determined in digestive gland using the UV assay with pyruvate by determining of the amount of NADH oxidation at $340 \mathrm{~nm}$ [7]. The extinction was read after every minute interval for a period of $4 \mathrm{~min}$. A molar extinction coefficient of $6.22 \cdot 10^{6} \mathrm{M}^{-1} \cdot \mathrm{cm}^{-1}$ was used.

Markers of Exposure. Vitellogenin-like proteins (Vtg-LP) were evaluated in gonads and hemolymph as alkali-labile phosphate level according to Blaise et al. (1999) [8]. Briefly, $200 \mathrm{ml}$ of gonad homogenates or $1.5 \mathrm{ml}$ hemolymph was mixed with t-butyl methyl ether for $30 \mathrm{~min}$ at room temperature. The ether phase was thoroughly mixed with $1 \mathrm{M} \mathrm{NaOH}$ for $60 \mathrm{~min}$ at $37^{\circ} \mathrm{C}$. The levels of free phosphates were determined by the phosphomolybdenum assay.

Metallothioneins (MTs) were determined from thiols measure with DTNB according to the method of Viarengo et al. (1997) after the ethanol/chloroform extraction. The levels of MTs were calculated assuming the relationship: $1 \mathrm{~mol}$ MTs $=20 \mathrm{~mol} \mathrm{GSH}$ and expressed as mg of MTs per gram of FW tissues [45].

Caspase-3 colorimetric assay was based on the hydrolysis of peptide acetyl-AspGlu-Val-Asp p-nitroanilide (Ac-DEVD-pNA) by caspase-3, resulting in a release of the $p$-nitroaniline ( $p N A)$ moiety. $p$-Nitroaniline was detected at $405 \mathrm{~nm}\left(\varepsilon_{\mathrm{mm}}=10.5\right)$. The concentration of the pNA released from the substrate was calculated from the absorbance values at $405 \mathrm{~nm}$ [9].

To assay the genotoxicity of water contaminants, the micronucleated hemocytes in hemolymph (MN) were calculated by the presence of miniature nuclei in the cytoplasm of postmitotic cells [4]. The frequencies of MN were expressed per 1,000 cells studied. Also nuclear lesions were scored into other categories: lobed nuclei (L), dumbbell-

ISSN 1996-4536 (print) • ISSN 2311-0783 (on-line) • Біологічні Студії / Studia Biologica • 2014 • Том 8/№1 • C. 11-28 
shaped or segmented nuclei (S), and kidney-shaped nuclei $(K)$. Cells with other than $\mathrm{MN}$ abnormalities were counted and the result was expressed as a mean value of the sums $(L+S+K)$ for all individual lesions observed per 1,000 cells. Not less than 2,000 cells were calculated in each sample.

Metal Determination. Zn, Cu and Cd concentration was measured in samples of weighed tissue of digestive gland $(250 \mathrm{mg})$ of each specimen, and pooled eluate of low weight thermostable proteins after chromatography $(10 \mathrm{~mL})$ in each group of mussels (in triplicate). Chromatography of thermostable extract was accomplished on Sephadex G-50, as described by Falfushynska et al. (2009) [15]. The samples were dried for $24 \mathrm{~h}$ at $105^{\circ} \mathrm{C}$, and then digested with $5 \mathrm{ml} \mathrm{HNO}_{3}$ for $3 \mathrm{~h}$ at $105^{\circ} \mathrm{C}$ under pressure, using an acid-cleaned Teflon bomb. The $\mathrm{Cu}$ and $\mathrm{Zn}$ content was analyzed by atomic absorption spectrophotometry against certified standards on spectrometer C-115, ("Lomo", Russia) and Cd, on graphite furnace atomic absorption spectrometer S-600 ("Selmi", Ukraine). The reliability of the measurements towards several of the selected elements was assessed by analyzing ERM-CE 278 certified reference material (mussel tissue); recoveries of metals were between $90 \%$ and $110 \%$.

Metal concentration in tissues and MTs forms was expressed as $\mu \mathrm{g} \cdot \mathrm{g}^{-1}$ fresh weight (FW), in MTs also - as $\mathrm{nmol} \cdot \mathrm{g}^{-1} \mathrm{FW}$.

Statistical Analysis. All measurements were expressed as means \pm standard deviation (SD) of 8 individuals for each biochemical parameters and of 14 individuals for each morphological index. To assess which biochemical indicator was the most affected by local conditions the index of inter-seasonal variability (VI) defined as the ratio between the maximal and minimal mean responses (IP = Mmax / Mmin) and was calculated for each biochemical parameters as average values during three seasons by Vidal M.-L. et al. (2002) [46].

Since data were not normally distributed (Lilliefors' test), non-parametric tests (Kruskall-Wallis ANOVA and Mann-Whitney U-test) were performed (significant at $p<0.05)$. Data were subjected to principal component analysis (PCA) to evaluate the biomarkers relation both in different sites and different seasons. Classification tree was built using the classification and regression tree (CART) software on the basis of all determined biological characteristics jointly in three seasons. CART builds the tree by recursively splitting the variable space based on the impurity of the variables to determine the split till the termination condition is met. Set of biological parameters were considered as predictor (independent) variables and site was considered as predictive (dependent) variable. The partitioning intends to increase the homogeneity of the two resulting subsets or nodes, based on the response variable. The partitioning stops when no splitting rule can improve the homogeneity of the nodes significantly.

All statistical calculations were performed with Statistica v 8.0 and Excel for Windows-2000.

\section{RESULTS}

Measurement of the morphologic indices of the mollusks showed a decrease in weight-related indexes during the summer at sites $\mathrm{F}$, and especially $\mathrm{N}$, when compared to the values in spring, with a further recovery or elevation in sites $A$ and $N$, but it remained low during autumn at site $\mathrm{F}$ (Table 1). In the site $\mathrm{N}$, most indices in the same seasons (periods III and IV) were not differed significantly.

ISSN 1996-4536 (print) • ISSN 2311-0783 (on-line) • Біологічні Студії / Studia Biologica • 2014 • Том 8/№1 • C. 11-28 
Table 1. Morphological indices of mollusks, M \pm S.D., $\mathbf{N}=12$

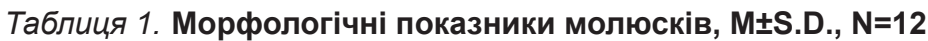

\begin{tabular}{|c|c|c|c|c|}
\hline Parameters & Period & $\mathrm{F}$ & A & $\mathrm{N}$ \\
\hline \multirow{4}{*}{ Body length (cm) } & $\mathrm{I}$ & $8.2 \pm 1.3$ & $8.3 \pm 1.4$ & $8.0 \pm 0.7$ \\
\hline & II & $7.4 \pm 0.3$ & $9.3 \pm 1.0^{a}$ & $8.2 \pm 0.6^{a}$ \\
\hline & III & $9.3 \pm 1.1$ & $9.2 \pm 0.7$ & $8.4 \pm 0.5^{\mathrm{a}}$ \\
\hline & IV & $8.2 \pm 0.9$ & $9.5 \pm 1.1^{\mathrm{a}}$ & $8.4 \pm 0.6$ \\
\hline \multirow{4}{*}{ Total body weight (g) } & 1 & $43.4 \pm 8.8$ & $32.8 \pm 13.1$ & $23.1 \pm 5.4^{a}$ \\
\hline & II & $35.4 \pm 8.1$ & $45.8 \pm 10.2^{\mathrm{a}}$ & $32.5 \pm 6.4$ \\
\hline & III & $51.1 \pm 11.5$ & $33.8 \pm 7.2^{\mathrm{a}}$ & $40.3 \pm 7.7^{b}$ \\
\hline & IV & $39.3 \pm 15.4$ & $50.9 \pm 20.4$ & $48.1 \pm 8.4$ \\
\hline \multirow{4}{*}{$\begin{array}{l}\text { Condition index of digestive gland } \\
\text { (tissue weight/total weight) }\end{array}$} & I & $1.7 \pm 0.3$ & $2.7 \pm 0.5^{\mathrm{a}}$ & $3.5 \pm 0.5^{\mathrm{a}}$ \\
\hline & II & $2.6 \pm 0.6^{b}$ & $2.0 \pm 0.3^{a}$ & $2.4 \pm 0.3^{b}$ \\
\hline & III & $2.3 \pm 0.3^{b}$ & $4.0 \pm 0.6^{a . b}$ & $3.2 \pm 0.6^{a}$ \\
\hline & IV & $2.6 \pm 1.0$ & $2.6 \pm 0.9$ & $3.2 \pm 0.3$ \\
\hline \multirow{4}{*}{$\begin{array}{l}\text { Condition index of gills } \\
\text { (tissue weight/total weight) }\end{array}$} & $\mathrm{I}$ & $4.2 \pm 0.6$ & $3.4 \pm 0.8$ & $6.7 \pm 0.8^{a}$ \\
\hline & II & $4.9 \pm 1.2$ & $4.2 \pm 0.6$ & $2.8 \pm 0.4^{a . b}$ \\
\hline & III & $2.7 \pm 0.5^{b}$ & $6.1 \pm 0.9^{a . b}$ & $5.0 \pm 0.6^{\text {a.b }}$ \\
\hline & IV & $3.9 \pm 1.1$ & $3.6 \pm 1.4$ & $3.4 \pm 1.1$ \\
\hline \multirow{4}{*}{ Condition factor (total weight/ $\mathrm{L}^{3}$ ) } & $\mathrm{I}$ & $10.6 \pm 1.7$ & $7.2 \pm 0.7^{\mathrm{a}}$ & $5.1 \pm 1.1^{\mathrm{a}}$ \\
\hline & II & $9.1 \pm 0.9$ & $5.7 \pm 0.7^{a}$ & $5.6 \pm 0.8^{a}$ \\
\hline & III & $7.1 \pm 1.4$ & $4.4 \pm 0.6^{\text {a.b }}$ & $6.9 \pm 0.7^{a . b}$ \\
\hline & IV & $7.4 \pm 1.3$ & $6.1 \pm 2.8$ & $8.2 \pm 1.0$ \\
\hline \multirow{4}{*}{ Length/shell } & $\mathrm{I}$ & $0.72 \pm 0.15$ & $1.00 \pm 0.25$ & $3.81 \pm 0.51^{a}$ \\
\hline & II & $0.29 \pm 0.04^{b}$ & $0.30 \pm 0.03^{b}$ & $0.41 \pm 0.07^{\text {a.b }}$ \\
\hline & III & $0.42 \pm 0.12^{\mathrm{b}}$ & $0.48 \pm 0.05^{b}$ & $0.35 \pm 0.06^{b}$ \\
\hline & IV & $0.31 \pm 0.11^{\mathrm{b}}$ & $0.32 \pm 0.10^{\mathrm{b}}$ & $0.32 \pm 0.05^{b}$ \\
\hline \multirow{4}{*}{ Shell/Total weight } & $\mathrm{I}$ & $0.22 \pm 0.05$ & $0.25 \pm 0.03$ & $0.09 \pm 0.01^{a}$ \\
\hline & II & $0.69 \pm 0.04^{\mathrm{b}}$ & $0.67 \pm 0.04^{b}$ & $0.66 \pm 0.04^{b}$ \\
\hline & III & $0.49 \pm 0.15^{\mathrm{b}}$ & $0.61 \pm 0.06^{b}$ & $0.62 \pm 0.05^{\text {a.b }}$ \\
\hline & IV & $0.60 \pm 0.11^{\mathrm{b}}$ & $0.65 \pm 0.01^{\mathrm{b}}$ & $0.64 \pm 0.10^{b}$ \\
\hline
\end{tabular}

Comments: ${ }^{a}$-statistically significant differences between sites; ${ }^{b}$-statistically significant differences between periods of sampling compared to I values. Always $P<0.05$.

Примітки: ${ }^{a}$ - відмінність між сайтами статистично вірогідна, ${ }^{b}$ - відмінність між періодами відбору статистично вірогідна порівняно зі значенням періоду I, P <0,05.

Study revealed seasonal variability of the indices of oxidative stress and Lactate dehydrogenase activity in all studied groups. The catalase activity was higher in the Agroup, particularly in autumn. In the $\mathrm{N}$-group from the cooling pond, its value was lesser among the groups of comparison in most cases (Fig. 2) On the other hand, the level of TBARS in the $\mathrm{N}$-group belonged to highest levels detected in this study, particularly in the summer.

The activity of LDH in the digestive gland demonstrated the inter-site variability in summer and autumn. In autumn it reached up to two-times higher level in the mussels from cooling pond. 
A

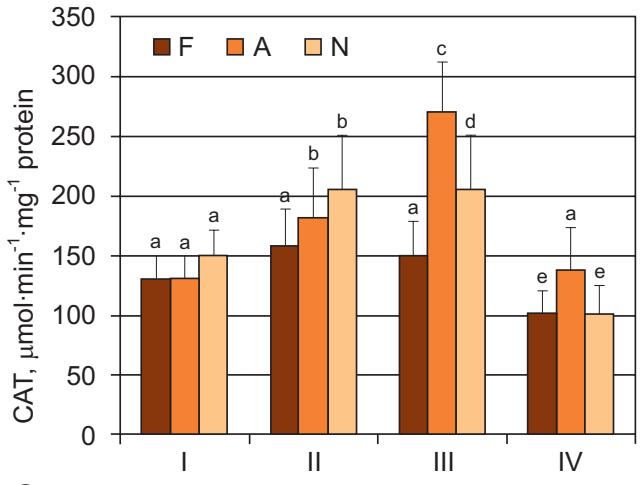

C

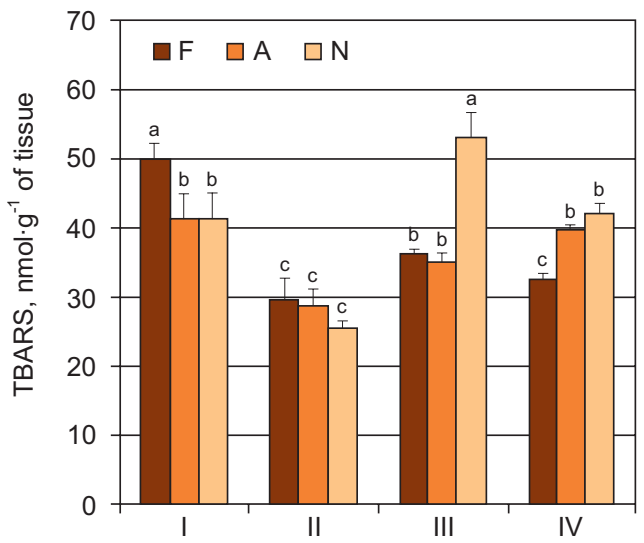

E

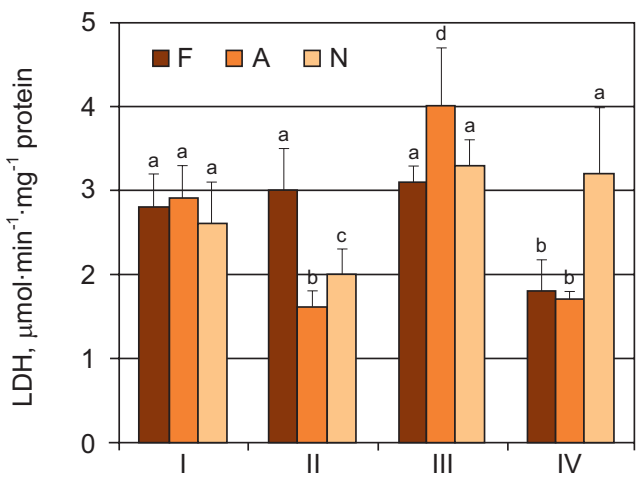

$B$

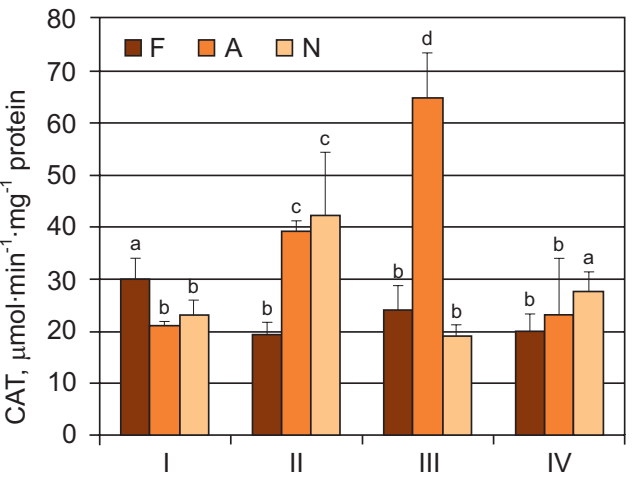

$D$

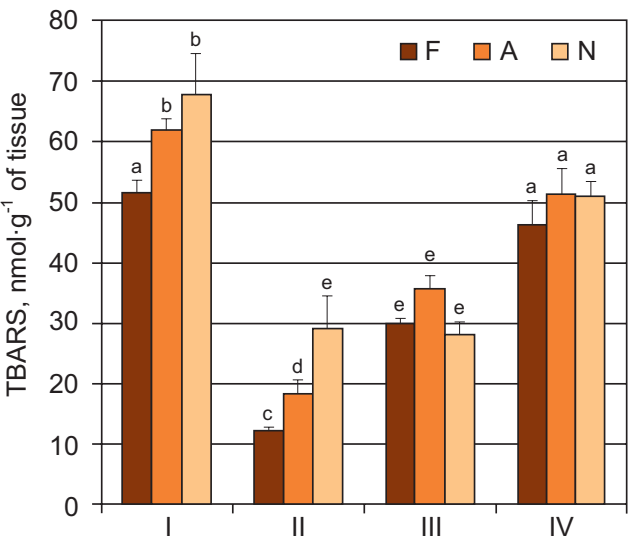

Fig. 2. Biochemical parameters of the oxidative stress ( $A, B$ - catalase activity; $C, D$-TBARS concentration) and lactate dehydrogenase activity $(E-L D H)$ in the digestive gland $(A, C, E)$ and gills $(B, D)$ of A. anatina in two years are presented as means \pm S.D. $(\mathrm{N}=8)$. In the Fig. $2-5$, the same letters correspond to values of biomarkers which do not differ significantly, always $\mathrm{P}>0.05$

Рис. 2. Біохімічні показники оксидативного стресу ( $A, B$ - каталазна активність; $C, D$ - концентрація ТБК-активних продуктів) і лактатдегідрогеназна активність (E - LDH) у травній залозі $(A, C, E)$ та зябрах (B, D) молюска A. anatina протягом двох років дослідження, представлені у вигляді середніх значень \pm S.D. $(\mathrm{N}=8)$. На рис. 2-5 однакові букви відповідають значенням біомаркерів, які істотно не відрізняються, $\mathrm{P}>0,05$ 
The level of GSH remained rather high in the N-group, whilst in the group from polluted agricultural area it was low in the most groups of comparison (Fig. 3). However, the levels of GSSG and Redox Index of GSH were in some cases extremely different in these mussels from other groups with higher value of GSSG and low value of RI GSH.

A Digestive gland

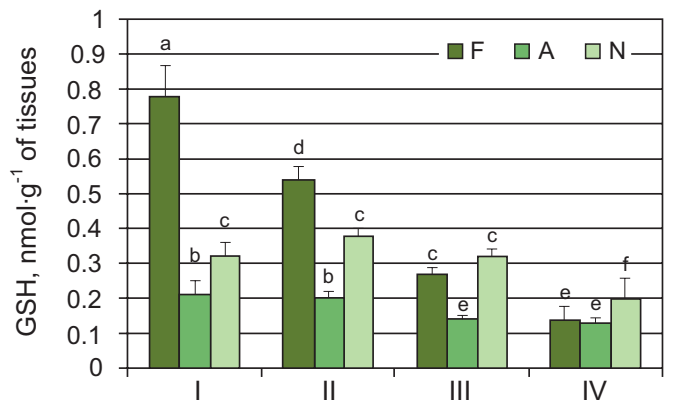

C

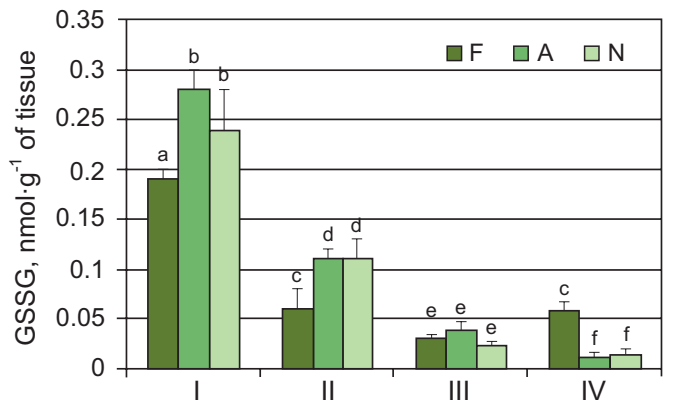

E

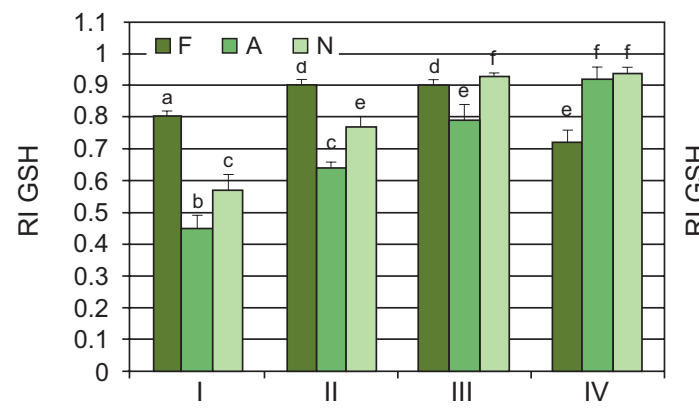

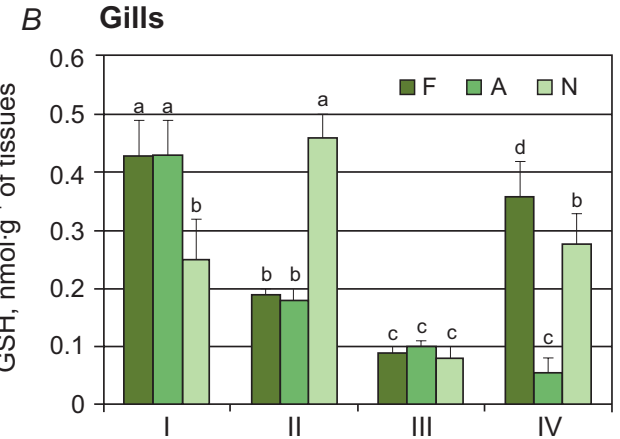

$D$

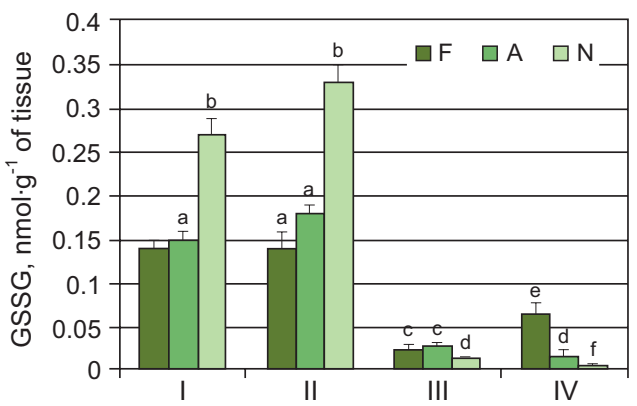

$F$

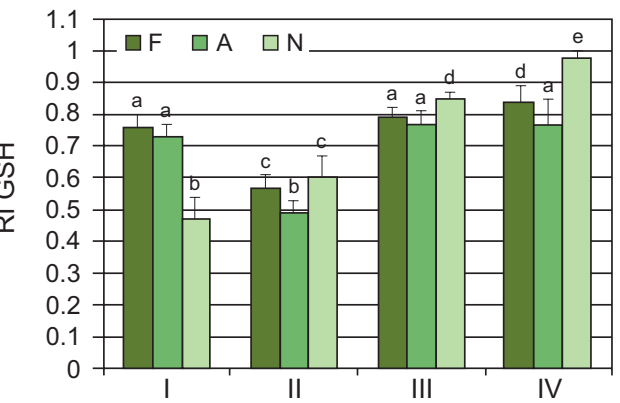

Fig. 3. Glutathione system in the digestive gland $(A, C, E)$ and gills $(B, D, F)$ of $A$. anatina, $\mathrm{M} \pm \mathrm{S} . \mathrm{D}$., $\mathrm{N}=8$. $A$, $B$ - reduced glutathione content; $C, D$ - oxidized glutathione content; $\mathrm{E}, \mathrm{F}$ : redox index of glutathione.

Рис. 3. Показники системи глутатіону в травній залозі $(A, C, E)$ та зябрах $(B, D, F)$ молюска $A$. anatina, $\mathrm{M} \pm \mathrm{S} . \mathrm{D} ., \mathrm{N}=8$. $A, B$ - вміст відновленого глутатіону; $C, D$ - вміст окисненого глутатіону; $E, F-$ peдокс-індекс глутатіону

The calculation of the Index of Variability of the characteristics of stress response demonstrated that the variability of GSSG concentration was most prominent in the Ngroup and belonged to main characteristics of variability for this site among all studied indices (Table 2). 
Table 2. Index of Variability (VI) of biochemical parameters in tissues of the digestive gland and gills of Anodonta anatina from forestry (F), agricultural (A) and cooling pond $(\mathrm{N})$ sites

Таблиця 2. Індекс варіабельності (VI) біохімічних показників у тканинах травної залози та зябер молюска Anodonta anatina, взятого з лісової (F), аграрної (A) місцевості та з водойми-охолоджувача (N)

\begin{tabular}{|c|c|c|c|}
\hline Parameters & Site & Digestive gland & Gills \\
\hline \multirow{3}{*}{ Catalase activity, $\mu \mathrm{mol} \mathrm{min}^{-1} \cdot \mathrm{mg}^{-1}$ protein } & $\mathrm{F}$ & 1.2 & 1.6 \\
\hline & A & 2.1 & 3.1 \\
\hline & $\mathrm{N}$ & 2.0 & 2.2 \\
\hline \multirow{3}{*}{$\mathrm{GSH}, \mu \mathrm{mol} \cdot \mathrm{g}^{-1}$ of tissue } & $\mathrm{F}$ & 2.9 & 4.8 \\
\hline & A & 1.5 & 4.3 \\
\hline & $\mathrm{N}$ & 1.2 & 5.8 \\
\hline \multirow{3}{*}{ GSSG, $\mu \mathrm{mol} \cdot \mathrm{g}^{-1}$ of tissue } & $\mathrm{F}$ & 6.1 & 5.6 \\
\hline & A & 7.4 & 6.2 \\
\hline & $\mathrm{N}$ & 10.0 & 23.6 \\
\hline \multirow{3}{*}{ TBARS, $\mathrm{nmol} \cdot \mathrm{g}^{-1}$ of tissue } & $\mathrm{F}$ & 1.7 & 4.2 \\
\hline & A & 1.4 & 3.4 \\
\hline & $\mathrm{N}$ & 2.1 & 2.4 \\
\hline \multirow{3}{*}{ LDH activity, $\mu \mathrm{mol} \cdot \mathrm{min}^{-1} \cdot \mathrm{mg}^{-1}$ protein } & $\mathrm{F}$ & 1.1 & 2.2 \\
\hline & A & 2.5 & 1.3 \\
\hline & $\mathrm{N}$ & 1.7 & 2.2 \\
\hline \multirow{3}{*}{ MT-SH, $\mu g \cdot g^{-1}$ FW } & $\mathrm{F}$ & 9.4 & 4.2 \\
\hline & A & 2.0 & 0.2 \\
\hline & $\mathrm{N}$ & 24.8 & 7.0 \\
\hline \multirow{3}{*}{ Caspase $3, \mathrm{pmol} \cdot \mathrm{mg}^{-1}$ of protein } & $\mathrm{F}$ & 12.6 & $\mathrm{X}$ \\
\hline & A & 2.2 & $x$ \\
\hline & $\mathrm{N}$ & 1.2 & $X$ \\
\hline
\end{tabular}

Comment: $\mathrm{X}$ - not determined.

Примітка: X - показник не визначали.

The assessment of the markers of exposure showed that the level of MT was highest in the N-group in the two seasons (Fig. 4). Besides that, MT level belongs to most variable indices for this group of mussels (Table 2). One of most remarkable molecular characteristics of the $\mathrm{N}$-group was stable elevated activity of caspase-3 (Fig. 4). It was accompanied by elevated level of the hemocytes with micronuclei and nuclear abnormalities, as compare to the reference F-group (Fig. 5). The level of caspase-3 and genotoxicity was particularly high in the second year of study.

The total and MT-related concentrations of $\mathrm{Cu}, \mathrm{Zn}$ and $\mathrm{Cd}$ in the digestive gland are represented in Fig. 6. Prominent seasonal differences were shown for metal concentration in the tissue and in MTs. In summer, in groups $F$ and A, highest levels of metals in MTs were indicated, and in the group $\mathrm{N}$, lowest their values were correspondent to this season. When three groups were compared, the concentration of $\mathrm{Cu}$ in MTs was always highest in group N. In spring and autumn periods, MTs in this group contained also highest concentrations of $\mathrm{Zn}$ and $\mathrm{Cd}$. Calculation of metal concentrations in MTs 
forms showed that the rate of $\mathrm{Zn}$ in MTs was up to ten-fold higher than $\mathrm{Cu}$, and only in group $\mathrm{N}$ in summer the rate of $\mathrm{Cu}$ in MTs was 1.5 fold higher than of $\mathrm{Zn}$. The concentration of MTs elevated prominently from spring to summer-autumn, especially in group $\mathrm{N}$. In summer and autumn, inter-site differences of MT concentration were detected with highest value for group $\mathrm{N}$ and lower for group $\mathrm{A}$.

According to PCA (Fig. 7, A), $60.65 \%$ of data belonged to Factors 1 and 2. The specimens from site $\mathrm{N}$ were located jointly, whilst the groups from other sites were

$A$

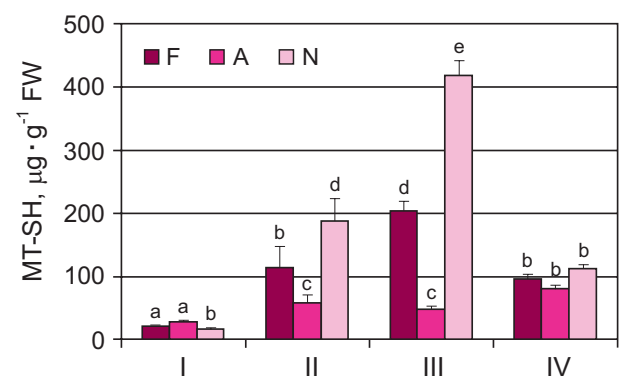

C

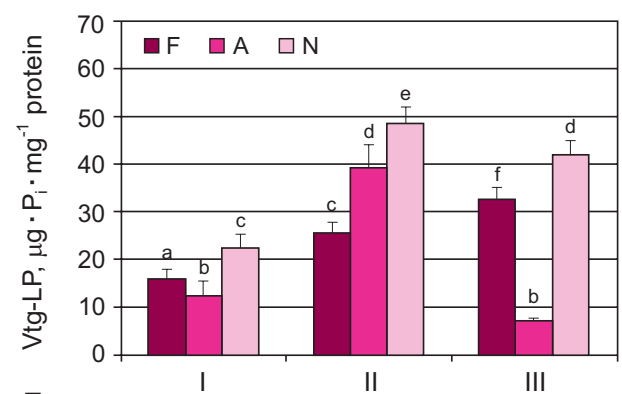

$E$

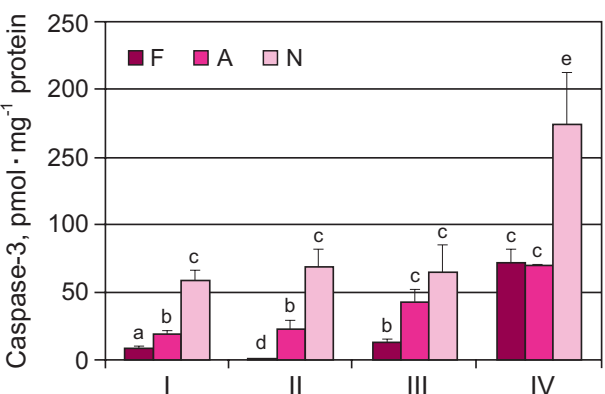

$B$

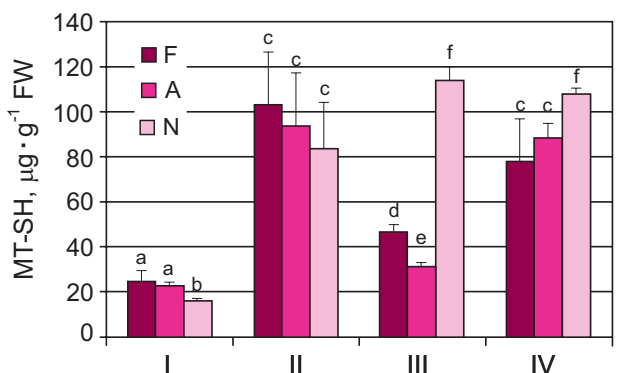

$D$

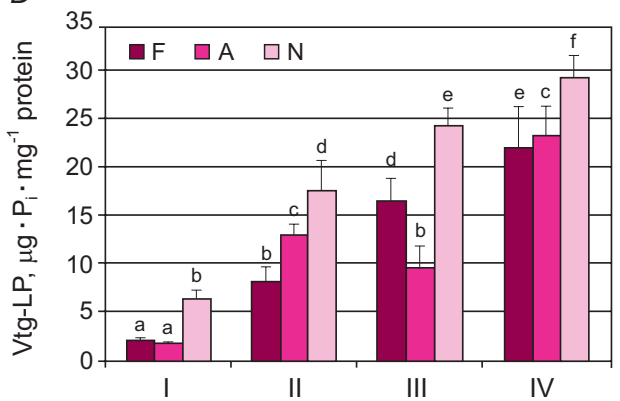

Fig. 4. Biomarkers of exposure in the tissues of $A$. anatina in two year, $M \pm S . D ., N=8: A$ - metallothioneins content in digestive gland; $B$ - metallothioneins content in gills; $C, D$-vitellogenin-like protein content in the hemolymph $(C)$ and gonad $(D) ; E$ - caspase-3 activity in the digestive gland. Significant effect, at $\mathrm{P}>0.05$

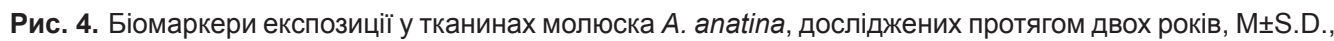
$\mathrm{N}=8: A$ - вміст металотіонеїну в травній залозі; $B$ - вміст металотіонеїну в зябрах; $C, D$ - вміст вітелогеніну в гемолімфрі $(C)$ та гонадах $(D)$; $E$ - активність каспази-3 у травній залозі. Відмінності вірогідні при $\mathrm{P}>0,05$ 
Fig. 5. Frequency of appearance of micronucleus (MN) and nuclear abnormalities (Other) in hemocytes of $A$. anatina from the sites $F, A, N$ in four periods of study, $\mathrm{M} \pm$ S.D., $\mathrm{N}=8$

Рис. 5. Частота появи мікроядер (MN) і ядерних аномалій (Others) у гемоцитах молюска $A$. anatina, взятого із місцевостей $F, A, N$ протягом чотирьох періодів дослідження, $\mathrm{M} \pm$ S.D., $\mathrm{N}=8$
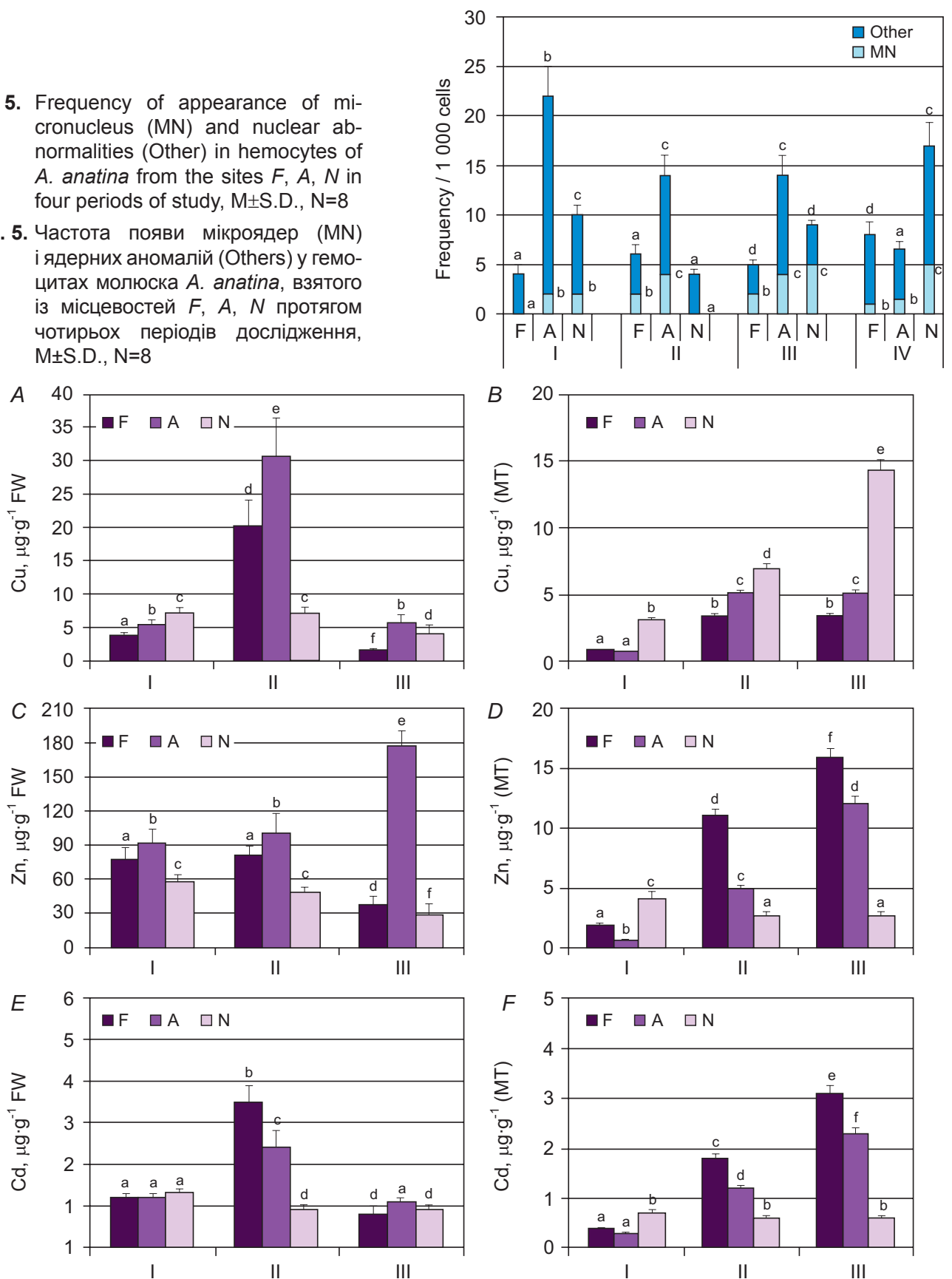

Fig. 6. Content of copper $(A, B)$, zinc $(C, D)$ and cadmium $(E, F)$ in the digestive gland tissue $(A, C, E)$ and in its low weight thermostable peaks (MTs) $(B, D, F)$ obtained by size-exclusive chromatography on a column with Sephadex G-50, $\mu \mathrm{g} \mathrm{g}^{-1} \mathrm{FW}, \mathrm{M} \pm \mathrm{S} . \mathrm{D}$.

Рис. 6. Вміст міді $(A, B)$, цинку $(C, D)$ і кадмію $(E, F)$ у тканинах травної залози $(A, C, E)$ та низькомолекулярних термостабільних фракціях $(\mathrm{MT})(B, D, F)$, отриманих після гель-розподільчої хромато-

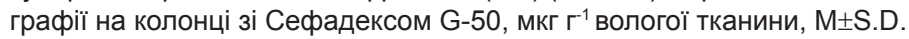




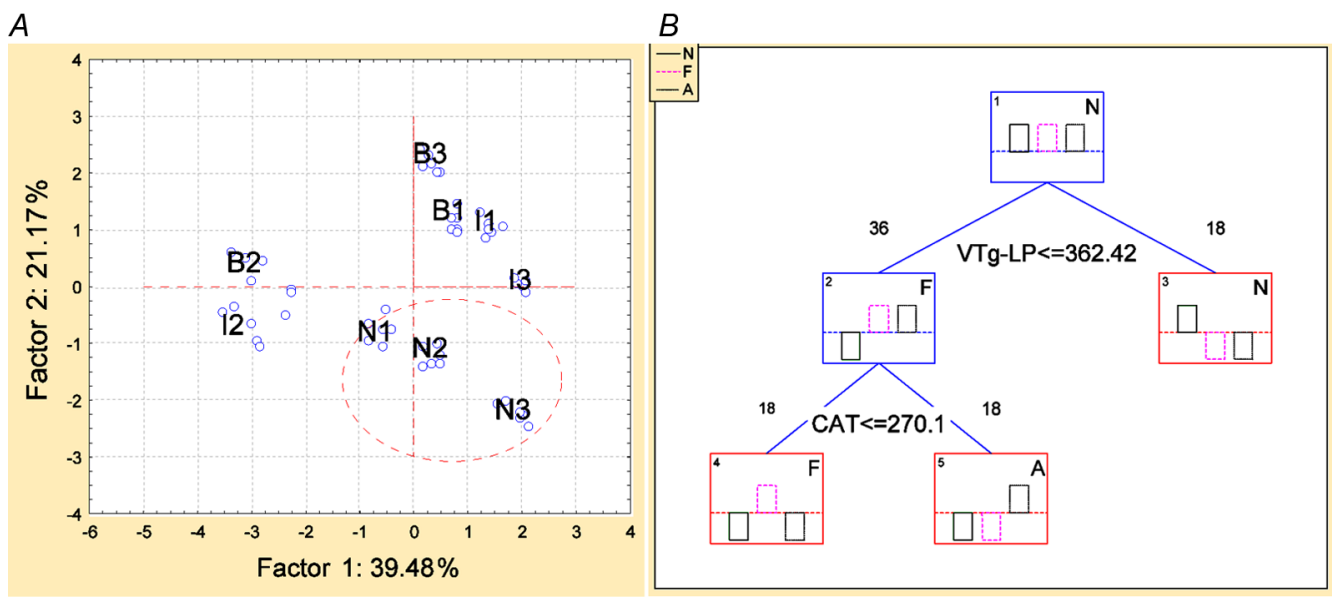

Fig. 7. Principal component analysis of the parameters data set in three sites in three seasons $(A)$ and Classification tree model $(B)$ : terminal nodes identify the dominant site and number of the mollusks that represented totality for all data

Рис. 7. Аналіз головних компонент набору показників із трьох місцевостей у трьох сезонах $(A)$ і модель класифікаційного дерева $(B)$ : термінальні відгалуження ідентифікують домінантний сайт і кількість молюсків, за показниками яких була відокремлена дана група

distributed in season-dependent regularity between different locations. So, despite the variability of GSSG level, the similarity of the responses of MT and caspase-3 determined the constant general characteristic of the specimens from this site. To elucidate main partitioning markers, we used the CART algorithm (Fig. 7, B). When all of the biological parameters at the three groups were compared, Vtg-LP level in the gonads was represented at the node as partitioning criterion for the groups $F$ and $N$. F and $A$ groups were separated by catalase activity in the digestive gland. The resulting confusion matrix showed an overall classification accuracy of $90 \%$. Any of the terminal nodes did not contained misclassified mussels. The best classification was predicted for group $\mathrm{N}$, followed by groups $\mathrm{F}$ and $\mathrm{A}$.

\section{DISCUSSION}

Despite an unique experience of the effect of stable elevated temperature in the cooling ponds of NPP, the data concerning the molecular responses of aquatic animals in such sites are scant. The mussels from typical polluted and reference field sites were studied previously, and the particularities of their responses were stressed [15]. For the newly selected group of mussels, derived from the $\mathrm{N}$-site, the industrial pollution, effect of low doses of radiation and also constantly elevated ambient temperature were suspected to be the reasons for the peculiarities of responses.

Elevated temperature provoked the activation of stress-related systems, as it is evident from our data and other results on mollusks [17, 42] and fish [31]. Two main characteristics of oxidative stress were distinguished in the mussels from site N. Firstly, a high lipid peroxidation level was found in summer period. Obviously, this peculiarity was caused by particularly high temperatures. It is known that high temperatures and temperature-related hypoxia in the aquatic animals affect the antioxidant defense system [42]. For example, similarly to the response of oxidative stress markers at site $\mathrm{N}$ 
in summer, long-term temperature stress has been associated with oxidative damage, decreased values of GSH and RI GSH and also increased activities of antioxidants in the gills of Perna viridis [43]. High rates of injury to mollusks at site $\mathrm{N}$ was confirmed by the fact that decreased weight and $\mathrm{Cl}$ of gills in summer were only found here. We can speculate that the limited ability to withstand high temperatures is because of high levels of anaerobic activity (high LDH activity). The metabolic depression and a shift from aerobic to anaerobic metabolism is a typical response to unfavorable conditions in mussels [3, 42, 49]. Pollution by toxic metals at this site may contribute to adverse environmental effect. The effect of increased temperature and exposure to $\mathrm{Cd}$ appeared to override a capability for aerobic energy production in a model marine bivalve, the eastern oyster Crassostrea virginica, resulting in impaired stress tolerance causing low condition index and elevated LPO [28].

Low weight intracellular thiols, GSH and MT, were selected by highest Index of Variability in the present study. It can be explained by as the most targeted their relation crucial biological functions in general stress response, particularly scavenging of reactive oxygen species, storage and transport of metal ions [10,44]. Up-regulation of these stress-related thiols is considered as one of the mechanisms involved in the adaptive response to low dose radiation exposure in aquatic animals [10,33]. On the other hand, the decreased level of GSH under the influence of low-level radiation (below $20 \mathrm{cSv}$ ), accompanied by increase of the level of lipid peroxidation products in human plasma, was revealed long after the accident (4-7 years) in the liquidators and children of exposed mothers from Chornobyl atomic power station area [26]. Incidentally, an opposite effect but also with high magnitude compare to the reference values, the elimination of MT but elevated GSH level was detected in the snails from the pond in the vicinity of Chornobyl area [21].

As reported Verlecar et al. (2007), increased activities of superoxide dismutase and other antioxidant enzymes but decreased values of GSH were indicated in the digestive glands of Perna viridis under long-term (14 days) exposure to elevated temperature [43]. Contradictory results in the present study could be explained by different regimes of heating. An increase of anaerobic glycolysis is well approved sign of toxic effect in mollusks [3]. This effect was shown in our study for the mussels from $\mathrm{N}$-site.

In mollusks from site N, the function of MTs was activated in autumn due to their defense against toxic metals. Group N was also distinguished by $\mathrm{Cu}$-enriched MTs. It was correspondent to highly elevated MT concentration in most cases. This group was also characterized by high levels of caspase-3 (constantly). The peculiarities of the environment in the sites related to the cooling ponds of NPP are studied scant. High level of $\mathrm{Cu}$ in the environment could be one of their attributes [16]. To date, two-year study in the vicinity of a NPP in northeastern France shown high levels of Cu in the area low sensitivity of indigenous Dreissena polymorpha to the spatial effects [24]. Elevated ambient temperature in the $\mathrm{N}$-site can provoke specific effects such as high MT and caspase-3 levels. These results are well coordinated with the information concerning the expression of heat shock proteins in goldfish inhabiting Gaobeidian Lake in Beijing, China. Water of this lake was reported to be moderately polluted and have an elevated temperature. The up-regulation of the heat shock proteins suggested that fish under these specific environmental conditions were experiencing a complex stress process [48]. Piano et al. (2004) reported that the levels of MT were significantly increased in the tissues of Ostrea edulis individuals exposed to thermal stress $\left(35^{\circ} \mathrm{C}, 1\right.$ hour $)$ and allowed to recover at $18{ }^{\circ} \mathrm{C}$ for 24 hours [34].

ISSN 1996-4536 (print) • ISSN 2311-0783 (on-line) • Біологічні Студії / Studia Biologica • 2014 • Том 8/№1 • C. 11-28 
Separate studies have been undertaken in Ukraine in the vicinity of NPPs, and absence of the effects of heated discharge waters of NPP on the zoobenthos was demonstrated [41]. However these studies were mostly conducted on the composition of populations and histochemical criterions. Elucidation of reasons for the biochemical abnormalities detected in our study at site $\mathrm{N}$, needs a more prolonged and comprehensive study.

Dreissena polymorpha populations in water basins near the ChNPS also showed no significant effect of radiations [18]. Besides, we explored a more comprehensive battery of biomarkers that showed an early warning of the effects of a nearby NPP whereas histological and morphological effects were less evident.

Despite information concerning the activity of caspases in bivalve mollusks being scant, caspase-3 activity seems to represent a valuable marker for the determination of toxic effects. Romero et al. (2011) reported that caspase genes in Mytilus galloprovincialis have extremely high expression levels within the gland and gills, where the apoptotic process is highly active due to the clearance of damaged cells, and the role of apoptosis in the defense against pathogens, contributes to the reasoning for including this assay in the set of biomarkers for mollusks [27, 29, 37]. In general, the activation of MTs and apoptotic functions in this group of mussels witness about successful response to heat stress in the mussels.

A high seasonal dependence for the biochemical markers of pollution is well known in marine mollusks, especially for oxidative stress related indices and MTs [21, 39, 47]. This can be explained by better conditions for growth and a faster metabolism due to optimal surrounding conditions (food availability, temperature). Studies of seasonal effects in freshwater mollusks are fragmental $[5,46]$. Nevertheless, seasonal regularity in the mussels from cooling pond was distorted as compare to the other sites, both clean and polluted. This peculiarity reflects obviously the effect of constantly elevated temperature in this pond.

Mollusks from sites $\mathrm{F}$ and $\mathrm{N}$ were distinguishing by levels of Vtg-LP. Only male mollusks were studied in order to avoid the effect of sex on Vtg-LP [20]. De Lafontaine et al. (2000) [13] showed a lack of significant effect of mussel size or sex on a response of this biomarker in bivalve Dreissena polymorpha. Therefore, we suggested that environmental estrogens were present at site $\mathrm{N}$, despite earlier skepticism concerning the validity of levels of Vtg-LP in the hemolymph of mollusks as a biomarker [20, 36].

In summary, a battery of non-specific markers of stress and markers of exposure and application of differential and classification tree analyses allowed imminent and persistent danger related to the endocrine disruption and activated apoptosis to be specified in the indigenous freshwater mollusks from NPP. The resilience of stress-related responses of cellular low-weight thiols could be classed as critical in these mussels.

\section{ACKNOWLEDGMENTS}

This work has been granted by the Ministry of Education and Science of Ukraine and State Fund of Fundamental Research of Ukraine (M/25-2009, M/25-2011, M/4-2013, \# 118B) and partly supported by the West Ukrainian BioMedical Research Center. The authors wish to thank Proof-Reading-Service.com for the linguistic and phraseological improvement of an earlier draft of this manuscript.

ISSN 1996-4536 (print) • ISSN 2311-0783 (on-line) • Біологічні Студії / Studia Biologica • 2014 • Том 8/№1 • C. 11-28 
1. Aebi H. Catalase. In: Bergmeyer H.U. (Ed.) Methods of Enzymatic Analysis. London: Academic Press, 1974: 671-684.

2. Anderson M.D. Determination of glutathione and glutathione disulfide in biological samples. Methods in Enzymology, 1985; 113: 548-555.

3. Anestis A., Lazou A., Pörtner H.O., Michaelidis B. Behavioral, metabolic, and molecular stress responses of marine bivalve Mytilus galloprovincialis during long-term acclimation at increasing ambient temperature. American Journal of Physiology - Regulatory, Integrative and Comparative Physiology, 2007; 293(2): 911-921.

4. Baršienè J., Andreikenaite L., Rybakovas A. Cytogenetic damage in perch (Perca fluviatilis L.) and duck mussel (Anodonta anatina L.) exposed to crude oil. Ekologija, 2006; 1: 25-31.

5. Baudrimont M., Lemaire-Gony S., Ribeyre F. et al. Seasonal variations of metallothionein concentrations in the Asiatic clam (Corbicula fluminea). Comparative Biochemistry and Physiology, 1997; 118 C(3): 361-367.

6. Bebianno M.J, Barreira L. Polycyclic aromatic hydrocarbons concentrations and biomarker responses in the clam Ruditapes decussatus transplanted in the Ria Formosa lagoon. Ecotoxicology and Environmental Safety, 2009; 72(10): 1849-1860.

7. Bergmeyer H.U., Bernt E. Lactate dehydrogenase U.V. assay with pyruvate and NADH. In: Bergmeyer H.U., Gawehn K. (Eds.). Methods of Enzymatic Analysis. New York: Academic Press, 1974; 574-579.

8. Blaise C., Gagne F., Pellerin J., Hansen P.D. Determination of vitellogenin-like properties in Mya arenaria hemolymph (Saguenay Fjord, Canada): A potential biomarker for endocrine disruption. Environ. Toxicol. Chem, 1999; 14(5): 455-465.

9. Bonomini M., Dottori S., Amoroso A. et al. Increased platelet phosphatidylserine exposure and caspase activation in chronic uremia. Thrombosis and Haemostasis, 2004; 2(8): 1-8.

10. Cai L., Satoh M., Tohyama Ch., Cherian M.G. Metallothionein in radiation exposure: its induction and protective role. Toxicology, 1999; 132(2-3): 85-98.

11. Contribution of Working Groups I, II and III to the Fourth Assessment Report of the Intergovernmental Panel on Climate Change. In: Pachauri R.K., Reisinger A. (Eds.). Climate Change 2007: Synthesis Report. Geneva, Switzerland: IPCC, 2007. 104 p.

12. Da Ros L., Meneghetti F., Nasci C. Field application of lysosomal destabilisation indices in the mussel Mytilus galloprovincialis: biomonitoring and transplantation in the Lagoon of Venice (north-east Italy). Marine Environmental Research, 2002; 54(3-5):817-822.

13. De Lafontaine Y., Gagné F., Blaise Ch. et al. Biomarkers in zebra mussels (Dreissena polymorpha) for the assessment and monitoring of water quality of the St Lawrence River (Canada). Aquatic Toxicology, 2000; 50(1-2): 51-71.

14. Falfushynska H.I., Delahaut L., Stolyar O.B. et al. Multi-biomarkers approach in different organs of Anodonta cygnea from the Dnister basin (Ukraine). Archives of Environmental Contamination and Toxicology, 2009; 57: 86-95.

15. Falfushynska H.I., Gnatyshyna L.L., Golubev A.P., Stoliar O.B. Main partitioning criteria for the characterization of the health status in the freshwater mussels Anodonta cygnea from spontaneously polluted area in Western Ukraine. Environ. Toxicol. Chem, 2012; 27(8): 485-494.

16. Falfushynska H.I., Stolyar O.B. Responses of biochemical markers in carp Cyprinus carpio from two field sites in Western Ukraine. Ecotoxicol. Environ. Saf, 2009; 72(3): 729-736.

17. Farcy E., Voiseux C., Lebel J.M., Fievet B. Seasonal changes in mRNA encoding for cell stress markers in the oyster Crassostrea gigas exposed to radioactive discharges in their natural environment. J. Environ. Eng. Sci, 2007; 374(2-3): 32-341.

18. Fetisov A.N., Rubanovich A.V., Slipchenko T.S., Shevchenko V.A. The structure of Dreissena polymorpha populations from basins adjacent to the Chernobyl atomic power station. J. Environ. Eng. Sci, 1992; 112(1): 115-124.

19. Frantsevich L., Korniushin A., Pankov I. et al. Application of molluscs for radioecological monitoring of the Chernobyl outburst. Environmental Pollution, 1996; 94(1): 91-100.

20. Gagnaire B. Gagné F. André C. et al. Development of biomarkers of stress related to endocrine disruption in gastropods: alkali-labile phosphates, protein-bound lipids and vitellogeninlike proteins. Aquatic Toxicology, 2009; 92(3): 155-167. 
21. Geffard A., Amiard-Triquet C., Amiard J.C. Do seasonal changes affect metallothionein induction by metals in mussels? Ecotoxicol. Environ. Saf, 2005; 61(2): 209-220.

22. Gnatyshyna L., Falfushynska H., Bodilovska O. et al. Metallothionein and glutathione in Lymnaea stagnalis determine the specificity of responses on the effects of ionising radiation. Radioprotection, 2012; 47(2): 231-242.

23. Griffith O.W. Determination of glutathione and glutathione disulfide using glutathione reductase and 2-vinylpyridine. Analytical Biochemistry, 1980; 106(1): 207-212.

24. Guerlet E., Ledy K., Meyer A., Giambérini L. Towards a validation of a cellular biomarker suite in native and transplanted zebra mussels: a 2-year integrative field study of seasonal and pollution-induced variations. Aquatic Toxicology, 2007; 81(4): 377-388.

25. Hagger J.A., Jones M.B., Leonard D. et al. Biomarkers and integrated environmental risk assessment: Are there more questions than answers? Environmental Management, 2006; 2(4): 321-329.

26. Ivanenko G., Goloshchapov A., Fatkullina L., Burlakova E. Relationship between plasma glutathione levels and lipid antioxidants of people exposed to low doses of radiation. Radioprotection, 2008; 43(5): 54.

27. Kiss T. Apoptosis and its functional significance in molluscs. Apoptosis, 2010; 15(3): 313321.

28. Lannig G., Flores J.F., Sokolova I.M. Temperature-dependent stress response in oysters, Crassostrea virginica: Pollution reduces temperature tolerance in oysters. Aquatic Toxicology, 2006; 79(3): 278-287.

29. Lockwood B.L., Sanders J.G., Somero G.N. Transcriptomic responses to heat stress in invasive and native blue mussels (genus Mytilus): molecular correlates of invasive success. Journal of Experimental Biology, 2010; 213(Pt 20): 3548-3558.

30. Lowry O.H., Rosebrough H.J., Farr A.L., Randall R.J. Protein measurement with Folin phenol reagent. J. Biol. Chem, 1951; 193: 265-275.

31. Lushchak V.I., Bagnyukova T.V. Temperature increase results in oxidative stress in goldfish tissues. 2. Antioxidant and associated enzymes. Comp. Biochem. Physiol, 2006; 143 C(1): 36-41.

32. Ohkawa H., Onishi N., Yagi K. Assay for lipid peroxidation in animal tissue by thiobarbituric acid reaction. Analytical Biochemistry, 1979; 95(2):351-358.

33. Olsvik P.A., Heier L.S., Rosseland B.O. et al. Effects of combined gamma-irradiation and metal $(\mathrm{Al}+\mathrm{Cd})$ exposures in Atlantic salmon (Salmo salar L.). Journal of Environmental Radioactivity, 2010; 101(3): 230-236.

34. Piano A., Valbonesi P., Fabbri E. Expression of cytoprotective proteins, heat shock protein 70 and metallothioneins, in tissues of Ostrea edulis exposed to heat and heavy metals. Cell Stress Chaperones, 2004; 9(2): 134-142.

35. Pourang N., Richardson C.A., Mortazavi M.S. Heavy metal concentrations in the soft tissues of swan mussel (Anodonta cygnea) and surficial sediments from Anzali wetland. Environmental Monitoring Assess, 2010; 163(1-4): 195-213.

36. Riffeser M., Hock B. Vitellogenin levels in mussel hemolymph - a suitable biomarker for the exposure to estrogens? Comp. Biochem. Physiol, 2002; 132(1):75-84.

37. Romero A., Estévez-Calvar N., Dios S. et al. New insights into the apoptotic process in mollusks: characterization of caspase genes in Mytilus galloprovincialis. PLoS ONE, 2011; 6(2): e17003.

38. Salánki J., Farkas V., Kamardina T., Rózsa K.S. Molluscs in biological monitoring of water quality. Toxicology Letters, 2003; 140-141: 403-410.

39. Sapoznikova Y., Zubcov N., Hungerford S. et al. Evaluation of pesticides and metals in fish of the Dniester River, Moldova. Chemosphere, 2005; 60(2): 196-205.

40. Sheehan D., Power A. Effects of seasonality on xenobiotic and antioxidant defence mechanisms of bivalve mollusks. Comp. Biochem. Physiol, 1999; 123 C(3): 193-199.

41. Silayeva A.A., Protasov A.A. Composition and structure of zoobenthos of Stir river in the zone of Rovenska AES and the evaluation of its effect on the bottom groups. Hydrobiologia, 2005; 41: $25-45$.

ISSN 1996-4536 (print) • ISSN 2311-0783 (on-line) • Біологічні Студії / Studia Biologica • 2014 • Том 8/№1 • C. 11-28 
42. Sokolova I.M. Energy-Limited Tolerance to Stress as a Conceptual Framework to Integrate the Effects of Multiple Stressors. Integr. Comp. Biol, 2013; 53(4): 597-608.

43. Stolyar O.B., Loumbourdis N.S., Falfushinska H.I., Romanchuk L.D. Comparison of metal bioavailability in frogs from urban and rural sites of Western Ukraine. Archives of Environmental Contamination and Toxicology, 2008; 54(1): 107-113.

44. Verlecar X.N., Jena K.B., Chainy G.B.N. Biochemical markers of oxidative stress in Perna viridis exposed to mercury and temperature. J. Biol. Chem, 2007; 167(3): 219-226.

45. Viarengo A., Lowe D., Bolognesi C. et al. The use of biomarkers in biomonitoring: a 2-tier approach assessing the level of pollutant-induced stress syndrome in sentinel organisms. Comp. Biochem. Physiol, 2007; 146(3): 281-300.

46. Viarengo A., Ponzano E., Dondero F., Fabbri R. A simple spectrophotometric method for metallothionein evaluation in marine organisms: an application to Mediterranean and Antarctic Molluscs. Marine Environmental Research, 1997; 44(1): 69-84.

47. Vidal M.-L., Bassères A., Narbonne J.-Fr. Influence of temperature, pH, oxygenation, watertype and substrate on biomarker responses in the freshwater clam Corbicula fluminea (Müller). Comp. Biochem. Physiol, 2002; 132 C(1): 93-104.

48. Vlahogianni T., Dassenakis M., Scoullos M.J., Valavanidis A. Integrated use of biomarkers (superoxide dismutase, catalase and lipid peroxidation) in mussels Mytilus galloprovincialis for assessing heavy metals' pollution in coastal areas from the Saronikos Gulf of Greece. Marine Pollution Bulletin, 2007; 54(9): 1361-1371.

49. Wang J., Wei Y., Li X. et al. The identification of heat shock protein genes in goldfish (Carassius auratus) and their expression in a complex environment in Gaobeidian Lake, Beijing, China. Comp. Biochem. Physiol, 2007; 145 C(3): 350-362.

50. Wu R.S.S, Lam P.K.S. Glucose-6-phosphate dehydrogenase and lactate dehydrogenase in the green-lipped mussel (Perna viridis): Possible biomarkers for hypoxia in the marine environment. Water Research, 1997; 31(11): 2797-2801.

\title{
МОЛЕКУЛЯРНІ РЕАКЦІЇ ДВОСТУЛКОВИХ МОЛЮСКІВ ІЗ ВОДОЙМИ-ОХОЛОДЖУВАЧА ЯК МОДЕЛЬ ДЛЯ ПРОГНОЗУВАННЯ СУЧАСНИХ ЕКОЛОГІЧНИХ ВИКЛИКІВ
}

\author{
Л. Л. Гнатишина', О. О. Турта' ${ }^{1}$ І. В. Юрчак', \\ Н. І. Бойко ${ }^{1}$, А. Є. Мудра', Г. І. Фальфушинська ${ }^{1,2}$, О. Б. Столяр ${ }^{1}$ \\ ${ }^{1}$ Тернопільський національний педагогічний університет імені Володимира Гнатюка \\ вул. М. Кривоноса, 2, Тернопіль 46027, Україна \\ e-mail: Oksana.Stolyar@gmail.com \\ ${ }^{2}$ Тернопільський державний медичний університет імені І.Я. Горбачевського \\ вул. М. Волі, 1, Тернопіль 46001, Україна
}

Для виявлення наслідків спільної дії забруднення та стабільно підвищеної температури на прісноводні організми порівнювали молекулярні реакції на стрес і токсичність середовища у двостулкового молюска Anodonta anatina зі ставу-охолоджувача Хмельницької AEC (N-група) та зі ставів у лісовій (F-група) і аграрній (А-група) місцевостях протягом двох років. За допомогою побудови класифікаційного та регресійного дерева на основі набору досліджених маркерів було виокремлено показники, за якими молюски N-групи істотно відрізнялися від інших груп. У першу чергу, це високий вміст вітелогенін-подібних білків у гонадах і гемолімфрі особин чоловічої статі як показник ендокринних розладів. У молюсків $\mathrm{N}$-групи спостерігали також ознаки оксидативного стресу з найвищим значенням Індексу міжсезонної варіабельності для окисненого глутатіону та металотіонеїн-залежних тіолів серед трьох груп, і стабільно високий рівень апоптичної активності у травній

ISSN 1996-4536 (print) • ISSN 2311-0783 (on-line) • Біологічні Студії / Studia Biologica • 2014 • Том 8/№1 • C. 11-28 
залозі. Крім того, відзначено високу концентрацію міді та кадмію у тканинах, що свідчить про індустріальне забруднення. Проте це метали були переважно зв'язані із метал-депонувальними протеїнами металотіонеїнами. Поєднання цих ознак свідчить, що стабільно підвищена температура спільно із промисловим забрудненням викликали часткове видалення клітин із ядерними ушкодженнями шляхом апоптозу та призвели до перевищення резистентності реакцій на стрес і фрункцій, пов'язаних із репродуктивною здатністю у молюсків.

Ключові слова: Anodonta anatina, тепловий ефект, забруднення, металотіонеїни, апоптоз, оксидативний стрес, ендокринні розлади.

\title{
МОЛЕКУЛЯРНЫЕ РЕАКЦИИ ДВУСТВОРЧАТЫХ МОЛЛЮСКОВ ИЗ ПРУДА-ОХЛАДИТЕЛЯ КАК МОДЕЛЬ ДЛЯ ПРОГНОЗИРОВАНИЯ СОВРЕМЕННЫХ ЭКОЛОГИЧЕСКИХ ВЫЗОВОВ
}

\author{
Л. Л. Гнатишина', О. О. Турта' ${ }^{1}$, И. В. Юрчак', \\ Н. И. Бойко ${ }^{1}$ А. Є. Мудра', Г.И. Фальфушинская ${ }^{1,2}$, О. Б. Столяр \\ ${ }^{1}$ Тернопольский национальный педагогический университет имени Владимира Гнатюка \\ ул. М.Кривоноса, 2, Тернополь 46027, Украина, \\ e-mail: oksana.stolyar@gmail.com \\ ${ }^{2}$ Тернопольский государственный медицинский университет имени И. Я. Горбачевского \\ ул. М. Воли, 1, Тернополь 46001, Украина
}

Для выяснения последствий совместного действия загрязнения и длительного потепления сравнивали молекулярные реакции на стресс и токсичность среды у двустворчатого моллюска Anodonta anatina из пруда-охладителя Хмельницкой АЭС (N-группа) и прудов в лесной (F-группа) и аграрной (А-группа) местностях в течение двух лет. C помощью построения классификационного и регрессионного дерева на основании набора исследованных показателей были отобраны показатели, по которым моллюски N-группы существенно отличались от других групп. В первую очередь, это повышенное содержание вителлогенин-подобных белков у особей мужского пола как показатель эндокринных расстройств. У моллюсков N-группы наблюдали также признаки оксидативного стресса с наиболее высоким значением Индекса межсезонной вариабельности для окисленного глутатиона и металлотионеин-зависимых тиолов среди трех групп и стабильно высокий уровень апоптической активности в пищеварительной железе среди трех групп. Кроме того, отмечен существенно более высокий уровень содержания меди, а также кадмия в тканях, что свидетельствует об индустриальном загрязнении. Однако эти металлы были преимущественно связаны с металл-депонирующими протеинами металлотионеинами. Сочетание этих признаков свидетельствует, что стабильно повышенная температура совместно с промышленным загрязнением способствовали удалению поврежденных клеток путем апоптоза и спровоцировали превышение резистентности реакций на стресс и фрункций, связанных с репродуктивной системой у моллюсков.

Ключевые слова:Anodonta anatina, тепловой эфрфект, загрязнение, металлотионеины, апоптоз, окислительный стресс, эндокринные расстройства.

Одержано: 07.10.2013

ISSN 1996-4536 (print) • ISSN 2311-0783 (on-line) • Біологічні Студії / Studia Biologica • 2014 • Том 8/№1 • C. 11-28 